\title{
Expression of homeo box genes during mouse development: a review
}

\author{
Peter W.H. Holland' and Brigid L.M. Hogan ${ }^{2,3}$ \\ ${ }^{1}$ Department of Zoology, University of Oxford, South Parks Road, Oxford OX1 3PS, UK; ${ }^{2}$ Department of Cell Biology, \\ Vanderbilt University Medical School, Nashville, Tennesse 37232 USA
}

The aim of this review is to summarize briefly what is presently known about the spatial and temporal patterns of homeo box gene expression during mouse development. Since information about mouse homeo box genes is accumulating very rapidly, this review does not offer a complete compendium of facts about topics such as gene sequence and organization. Instead, we have tried to assemble rather fragmentary published and unpublished data about expression into a tentative framework which may provide some clues as to the function of these genes. To simplify our analysis, we have concentrated upon three different stages of mouse development; early presomite gastrula $\left(7-7.75\right.$ days post coitum $\left.{ }^{*}\right)$, early somite neurula (8-8.5 days p.c.), and a stage about twothirds through gestation (12.5 days p.c.) when most of the organ systems have been established but are still undergoing morphogenesis. Detailed accounts of the anatomy of these embryos and the overall process of mouse development can be found in Snell and Stevens (1966), Theiler (1972), Rugh (1968), and Hogan et al. $(1985,1986)$.

The homeo box is a DNA sequence of about $180 \mathrm{bp}$, originally identified within the coding region of several Drosophila genes controlling embryonic development (for review, see Gehring 1987). It is generally accepted that the protein products of Drosophila homeo box genes act as sequence-specific DNA binding proteins, regulating gene expression. This suggestion is consistent with the nuclear localization of several Drosophila homeo box gene products (White and Wilcox 1984; Beachy et al. 1985; Carroll and Scott 1985; Di Nardo et al. 1985), with their reported in vitro DNA binding properties (Desplan et al. 1985), and with their predicted protein structure (Shepherd et al. 1984; Laughon et al. 1985).

Drosophila homeo box genes constitute a rather variable gene family. DNA sequence comparisons, primarily of the homeo box region itself, indicate that classes of genes exist within which the genes share a more recent evolutionary origin than that shared by the homeo box gene family as a whole. The most extensive class, for which Antennapedia (Antp) is the prototype, contains several of the Drosophila homeotic genes (including Antp, Sex combs reduced, Deformed, and infraabdo-

\footnotetext{
${ }^{3}$ To whom reprint requests should be addressed.

* Midday on the day of the vaginal plug is 0.5 day post coitum. However, developmental ages can vary between embryos in a litter, and between inbred and outbred strains of mice.
}

minal-7; see Gehring 1987). Other recognized classes of Drosophila homeo box genes contain only one or a few characterized genes. For example, engrailed (en) and invected comprise the en-like class (Poole et al. 1985; Coleman et al. 1987), whereas three other genes contain a paired-like homeo box (Bopp et al. 1986).

About 20 homeo box genes have so far been identified in the mouse. Sequence comparisons indicate that most of these genes are related to the Antp-like class of Drosophila, whereas two have homeo box sequences more similar to the en-like genes. Current nomenclature (Martin et al. 1987) designates each member of the first class by a number after the prefix ' $\mathrm{Hox}^{-}$,' while the two members of the second class have the prefix 'En-'. Many of the Hox-genes are organized into clusters, of which the largest, Hox-1 and Hox-2, contain at least six genes each and span over $70 \mathrm{~kb}$ on mouse chromosomes 6 and 11 , respectively. Genes within a cluster are numbered in the order in which they were characterized. In addition to the Hox- and En-genes, there are other more divergent homeo box genes present in the mouse, but such genes remain to be well characterized. More discussion of the organization, and DNA sequence comparisons, of mouse homeo box genes can be found in other recent reviews and papers (Burglin et al. 1987; Colberg-Poley et al. 1988; Fienberg et al. 1987; Hart et al. 1987; Lonai et al. 1987; Martin et al. 1987).

It may be significant that close genetic linkage has been established between some mouse homeo box genes and known developmental mutations, e.g., between En-1 and Dominant hemimelia (Hill et al. 1987; Joyner and Martin 1987); En-2 and Hemimelic extra toes, Hammertoe, and reeler (Joyner and Martin 1987); the Hox-1 cluster and Hypodactyly (Mock et al. 1987; Rubin et al. 1987); and the Hox-2 cluster and tail short (Munke et al. 1986; Fienberg et al. 1987). However, it should be stressed that allelism has not been demonstrated in any of these cases.

Most studies of homeo box gene expression in the mouse embryo have been concerned with steady-state RNA levels. At present there are few specific antibodies against mouse homeo box proteins available, and their application to analyzing gene expression during embyrogenesis has so far been limited to En-1 (M. Frohman and G. Martin, pers. comm.). However, antibodies have been used to demonstrate that the protein products of mouse Hox-1.1 (Kessel et al. 1987; Schulze et al. 1987), Hox-1.3 (Odenwald et al. 1987), and En-1 (M. Frohman and G. 
Martin, pers. comm.) are localized predominantly in the nucleus, consistent with the in vitro DNA-binding property demonstrated by the Hox-1.5 product (Fainsod et al. 1986). By focusing on RNA studies we may be oversimplifying the issues, since it is possible that there are spatial and temporal variations in transcription start sites, splicing, and protein modification, for example. Nevertheless, we feel that it is worthwhile to take stock of present information, and to see if it supports any useful speculation about the nature of the developmental processes that may be regulated by mammalian homeo box genes. We conclude that the patterns of expression seen are consistent with a role for homeo box genes in the determination of cell fate; an example of this role may be to establish anteroposterior domains of positional value in the mammalian embryo.

\section{Early presomite gastrula (about 7.5-7.75 days post coitum; stage 11 of Theiler 1972)}

Before gastrulation, the mouse embryo consists of two epithelial sheets, the primitive ectoderm and the visceral endoderm /containing about 600 and 250 cells, respectively), folded into a cup-shaped structure known as the egg cylinder. Gastrulation begins when cells delaminate from the primitive ectoderm to generate a population of individual mesodermal cells between the ectoderm and visceral endoderm. This process starts at the posterior end of the egg cylinder, in a region known as the primitive streak (see Fig. 1A) and continues for about $24 \mathrm{hr}$, during which time the anterior-posterior body axis becomes apparent and the metamerism of the mesoderm is established. Unfortunately, no detailed lineage studies have yet been completed of gastrulation in the mouse, but indirect experiments generally support the idea that gastrulation movements and fate maps are similar in mammalian and avian embryos (reviewed by Snow 1985; Vakaet 1985). It is assumed that the first mesoderm cells to delaminate through the primitive streak end up beneath the neural folds and in the region of the presumptive heart; they never aggregate into somites, but in the head form loose condensations known as somitomeres. Mesoderm that delaminates later remains at first in an apparently unorganized state (presomitic mesoderm) before aggregating into visible somites (Poelmann 1981; Meier and Tam 1982; Tam and Meier 1982; Tam et al. 1982; Nakatsuji et al. 1986).

Although a number of studies have been made of homeo box gene expression at the presomite stage of development, the only positive evidence for differential spatial expression comes from the in situ hybridization studies of Gaunt (Gaunt et al. 1986; Gaunt 1987, 1988), using probes for Hox-1.5 and Hox-3.1. He detects no expression of either gene before 7.5 days p.c. (for example, at the stage shown in Fig. 1A). Around 7.5-7.75 days, however, expression of Hox-1.5 RNA is clearly detectable, and is higher in posterior presomitic mesoderm and ectoderm than in anterior tissues (Fig. 1B,C). Weaker expression is also seen in the allantois. This tissue is derived from mesoderm which migrates from the posterior end of the primitive streak and eventually contributes to
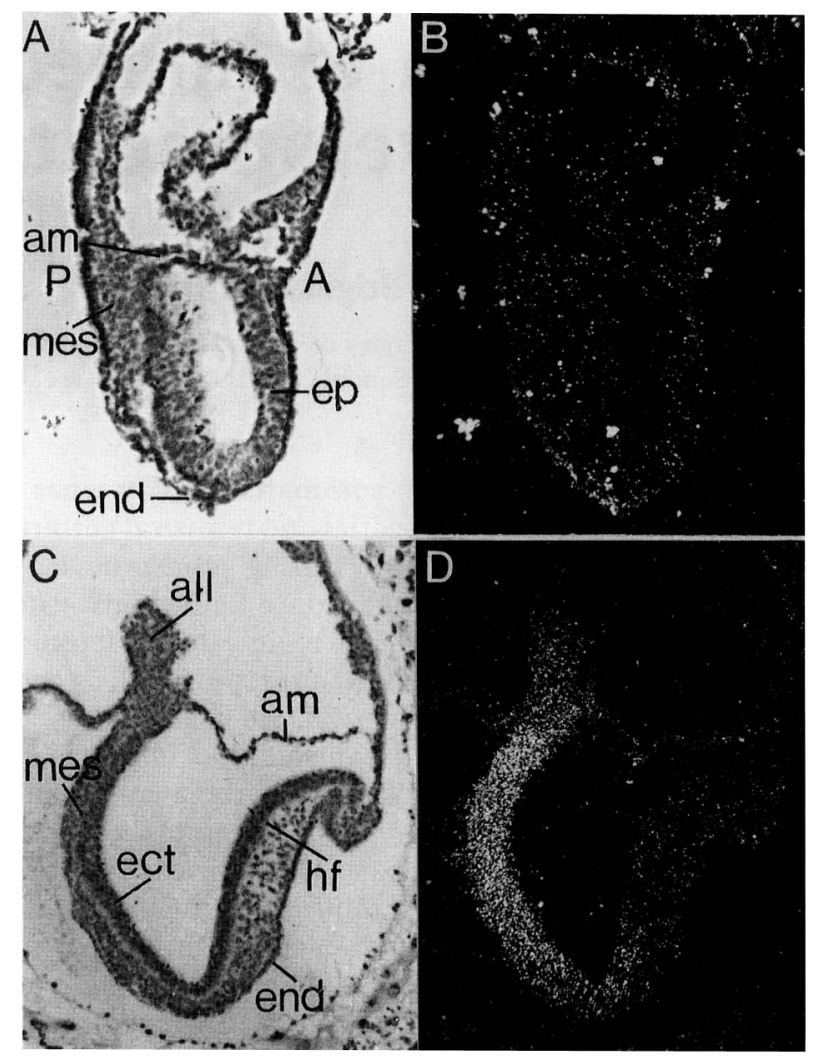

Figure 1. Presomite mouse embryos. $(A, B)$ Sagittal section of 7.25-day post coitum embryo hybridized with antisense Hox-1.5 probe. Mesodermal cells (mes) are beginning to accumulate between the posterior primitive ectoderm or epiblast (ep) and the visceral endoderm (end). (A) Anterior; (P) posterior; (am) amnion. (B) Dark-ground illumination. No significant expression of any homeobox gene has so far been detected at this stage by in situ hybridization. $\{C, D\rangle$ Expression of Hox-1.5 in the 8-day p.c. embryo. $(B)$ Bright-field and $(C)$ dark-ground illumination of sections hybridized with antisense Hox-1.5 probe. Note uniform expression in both the posterior presomite mesoderm and overlying ectoderm. The grain density in the anterior region is not significantly higher than with the positive sense strand probe (see Gaunt 1987). (mes) Posterior mesoderm; (hf) head fold neurectoderm with anterior mesoderm; (end) endoderm; (all) allantois; (am) amnion. Because the outer visceral endoderm layer is so thin, it is not known whether this germ layer is positive for expression or not. (Photomicrographs kindly provided by Dr. S. Gaunt.) (See Gaunt 1987.)

extraembryonic blood vessels. Hox.3-1 RNA is also first detected around 7.5 days p.c., predominantly localized to the allantois. Careful in situ analysis has shown that Hox-1.5 transcripts accumulate slightly earlier than those of Hox-3.1 (Gaunt 1988), so that the two genes show not only a spatial but also a temporal difference in expression, even at this early stage.

Expression of $H o x-2.1$ and En-2 could not be detected in presomite embryos by in situ hybridization (Davis et al. 1988; Holland and Hogan 1988). However, RNase protection or Northern analysis, using RNA pooled from a large number of embryos, has revealed very low levels of Hox-2.1 and Hox-1.3 RNA at 7.5 days p.c. (Jackson et al. 1985; Odenwald et al. 1987). Improvements in sensi- 
tivity for in situ hybridization and use of antibody probes would clearly facilitate analysis of these genes in presomite embryos.

Early somite stage embryos (about 6 somites, 8-8.5 days post coitum; stage 12 of Theiler 1972)

As the embryo grows, the primitive streak extends and the total amount of mesoderm tissue increases rapidly. In the midline, some mesoderm cells differentiate into a rod of tissue known as the notochord, while on either side of the notochord paired somites gradually condense in an anterior-to-posterior sequence. Cells furthest from the midline do not contribute to metameric or repeating structures and are known as the lateral plate mesoderm. The intermediate mesoderm, which connects the somites and the lateral plate, also shows metamerism, in register with that of the somites. Eventually, the condensed somites will break up and give rise to a number of different tissues. The part known as the dermatome forms mesoderm in the skin, the myotome forms muscle, and the sclerotome gives rise to vertebrae around the spinal cord. During this process, the sclerotomes are referred to as prevertebrae. It is important to note that not all the somites give rise to vertebrae; in the mouse embryo the first four or five somites contribute to part of the skull, so that the first vertebra (the atlas) is derived from the fifth or sixth somite. It is also generally accepted (but, in the absence of good lineage marking, not rigorously proven) that each vertebra is derived from the fusion of the posterior half of one sclerotome and the anterior half of the next. These complications lead to some ambiguities in numbering the somites as cervical, thoracic, etc., so that in Figure 3 we have simply numbered them in straight sequence.

By the five- to six-somite stage, expression of a number of homeo box genes can be detected clearly by in situ hybridization (i.e., Hox-1.3, -1.5, -2.1, -3.1, -6.1, En-2). However, as shown in Figure 3, the spatial limits of expression vary for the different genes. Of particular interest is the expression of Hox-1.5, which a few hours earlier was confined to posterior mesoderm and ectoderm and was about equal in both tissues (Fig. 1B,C). At the early somite stage the spatial domains of Hox-1.5 expression appear to become spatially dissociated in mesoderm and ectoderm. RNA levels decline significantly in the mesoderm, but remain high in the ectoderm where they extend anteriorly to the posterior $\epsilon$ nd of the neural folds (see open arrow in Fig. 2) (Gaunt 1987). This position corresponds to the anterior limit of Hox-1.5 expression in later (10.5 days p.c.) embryos, in which the neurectoderm has folded up into the neural tube and brain. For Hox-1.5 the anterior limit is the midpoint of one of the repeating neuromeric swellings in the myelencephalon, just anterior to the otic vesicle (Fainsod et al. 1987; Gaunt 1987). Subsequently, there is no significant shift in this anterior boundary of Hox-1.5 in the central nervous system (CNS) between 8.5 and 12.5 days of development (Fig. 3).

The level of expression of Hox-2.1 appears to be lower than Hox-1.5 but, in general, shows the same pattern at this stage, although the anterior limit of hybridization in the neural folds has not been so well defined (Holland and Hogan 1988). In contrast, Hox-6.1,-1.3,-3.1, and En-2 show very different patterns of RNA distribution to Hox-1.5 and -2.1 (Fig. 2). Hox-6.1 RNA is confined to the posterior mesoderm, which has not yet condensed into somites, to the overlying ectoderm, and to the allantois (Sharpe et al. 1988). Similarly, Hox-1.3 expression is reported to be confined to presomitic mesoderm (Dony and Gruss 1987). En-2, on the other hand, shows a narrow band of high-level expression in the neural folds in the region of the foregut pocket. No expression is seen in the underlying anterior mesoderm, or in other ectodermal or mesodermal derivatives (Davis et al. 1988). As development proceeds, En-2 expression is maintained in structures derived from this narrow band of neural tissue, namely in a large part of the metencephalon at 12.5 days p.c., and in the cerebellum, pons, and superior and inferior colliculus at later stages still. In other words, the domain of En-2 expression along the anterior-posterior axis of the CNS does not change significantly in spite of the extensive morphogenetic events that take place between 8 and 12.5 days (and later).

Expression of Hox-3.1 has also been detected in early somite stage mouse embryos by in situ hybridization. RNA is reported to be localized to the posterior regions, and apparently is equally abundant in neurectoderm, presomitic mesoderm, and allantois (Gaunt 1988). In slightly more advanced embryos, after the body axis has 'turned,' Hox-3.1 RNA is also detected in hindgut endoderm (Le Mouellic et al. 1988).

Embryos about two-thirds through gestation (12.5 days p.c.; stage 20 of Theiler 1972)

This stage of embryogenesis has been studied most extensively for homeo box gene expression, because in many cases it is the time when maximal transcript levels are seen by Northern or RNase protection analysis of total embryo RNA /Colberg-Poley et al. 1985; Jackson et al. 1985; Awgulewitsch et al. 1986; Joyner and Martin 1987; Rubin et al. 1987). By this time, all the major systems of the body have been established. Briefly, the somites posterior to somites 5 or 6 give rise to vertebrae, skin mesoderm, and muscle blocks, as described in the previous section. The lateral plate mesoderm has split into two sheets; the somatopleure, which gives rise to muscle and connective tissue in the body wall and the limb buds, and the splanchnopleure, which gives rise to mesodermal tissues enveloping the gut. Between the somitic mesoderm and lateral plate mesoderm there is a strip of mesoderm, loosely termed the intermediate mesoderm, which gives rise to the segmented nephrotomes of the pronephros, mesonephros, and metanephric kidney. However, the precise origin of the mesoderm that contributes to organs such as the lung, liver, and stomach, and genital ridges is not clear; for convenience, we will call it lateral plate mesoderm, although it may be closer spatially to intermediate mesoderm (Le Douarin 1964). Figure 3 shows the approximate levels 


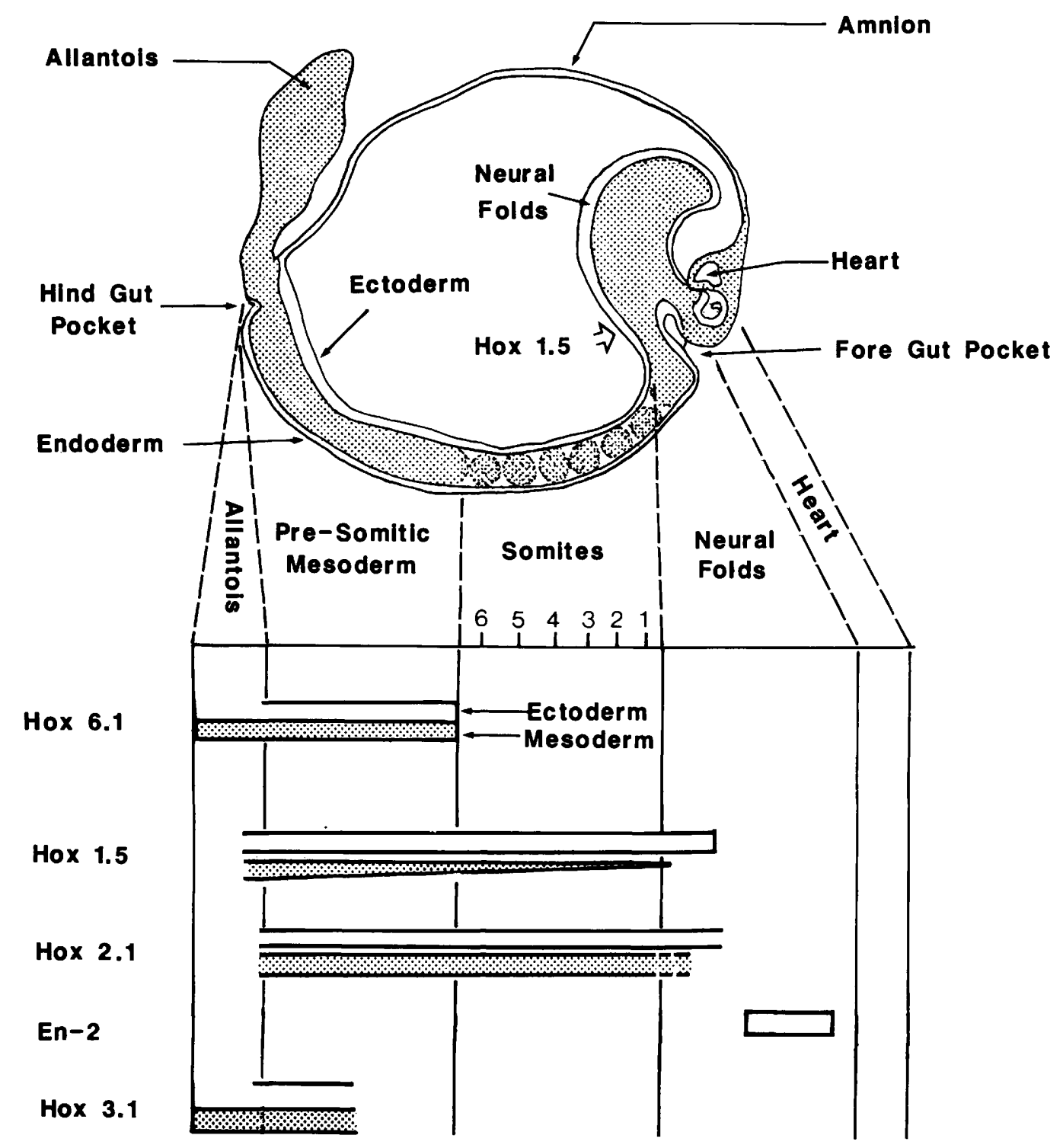

Figure 2. Schematic representation of domains of expression of mouse homeo box genes in the six-somite neurula-stage mouse embryo (approx. 8 days p.c.). Mesoderm is stippled. No expression of En-2 is seen in the mesoderm. References: Hox-6.1, Sharpe et al. (1988); Hox-1.5, Gaunt (1987); Fainsod et al. (1987); Hox-2.1, Holland and Hogan (1988); En-2, Davis et al. (1988); Hox-3.1, Gaunt (1988); LeMouellic et al. (1988).

along the anterior-posterior axis at which the mesoderm of visceral organs is thought to arise in the mouse embryo. As discussed elsewhere (Holland and Hogan 19881, the evidence for this comes largely from cellmarking studies on the chick embryo (Le Douarin 1964, 1982). More precise localization of the origin of meso- derm of the internal organs of the mouse is a major challenge for future lineage work.

By 12.5 days p.c. the central nervous system has clearly differentiated into spinal cord and brain, which is further subdivided anatomically into pros-, mes-, met-, and myelencephalon (Fig. 3). During development, the

Figure 3. Schematic summary of mouse homeo box gene expression in the 12.5-day embryo. Vertical lines representing the limits of expression of homeo box genes are determined by in situ hybridization of sagital sections of 12.5- to 13.5-day p.c. embryos. In some cases the posterior limit is only approximate. Absence of expression, where clearly reported, is noted at the bottom of each panel. In the right-hand part of the diagram, a cross means positive expression has been seen by in situ hybridization, and a minus sign means no expression. A blank means expression has not been reported. For assignment of position along the anterior-posterior axis for mesoderm of organ rudiments see Le Douarin (1964, 1982) and Holland and Hogan (1988). (Pros) Prosencephalon; (mes) mesencephalon; (met) metencephalon; (myel) myelencephalon; (V, VII, VIII, IX, X) cranial nerves; (At) atlas; (Ax) axis. Data are from ColbergPoley et al. (1988); Davis et al. (1988); Dony and Gruss (1987); Fainsod et al. (1987); Gaunt (1987, 1988); Fienberg et al. (1987); Graham et al. (1988); Holland and Hogan (1988); Le Mouellic et al. (1988); Sharpe et al. (1988); Toth et al. (1987); Utset et al. (1987); G. Dressler, M. Frohman, S. Gaunt, A. Graham, P. Gruss, G. Martin, K. Mahon, (pers. comm.). 


\begin{tabular}{|c|c|c|c|c|}
\hline $1.9 \times O H$ & 1 & ++ & + & + \\
\hline I'E $\times$ он & 1 & 11 & + & + \\
\hline $9.2 \times 0 \mathrm{H}$ & I & ++ & & \\
\hline $12 \mathrm{C} \times \mathrm{OH}$ & 1 & ++ & + & + \\
\hline S.L XOH & I & ++ & + & + \\
\hline E'L XOH & 1 & ++ & & + \\
\hline
\end{tabular}

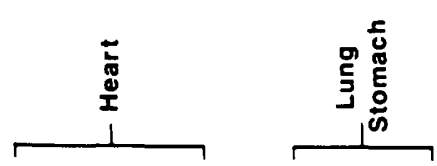

[

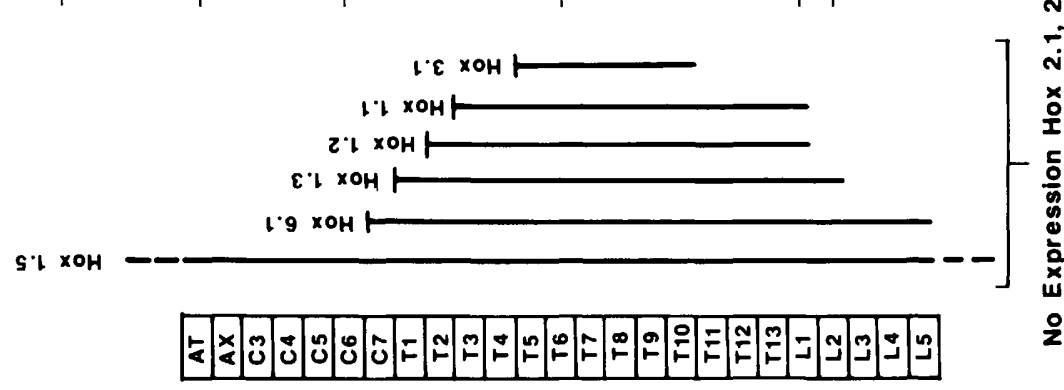

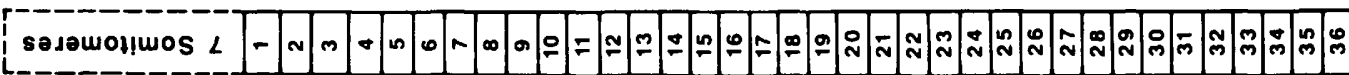

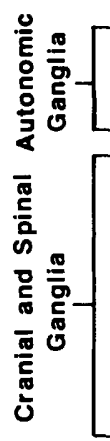
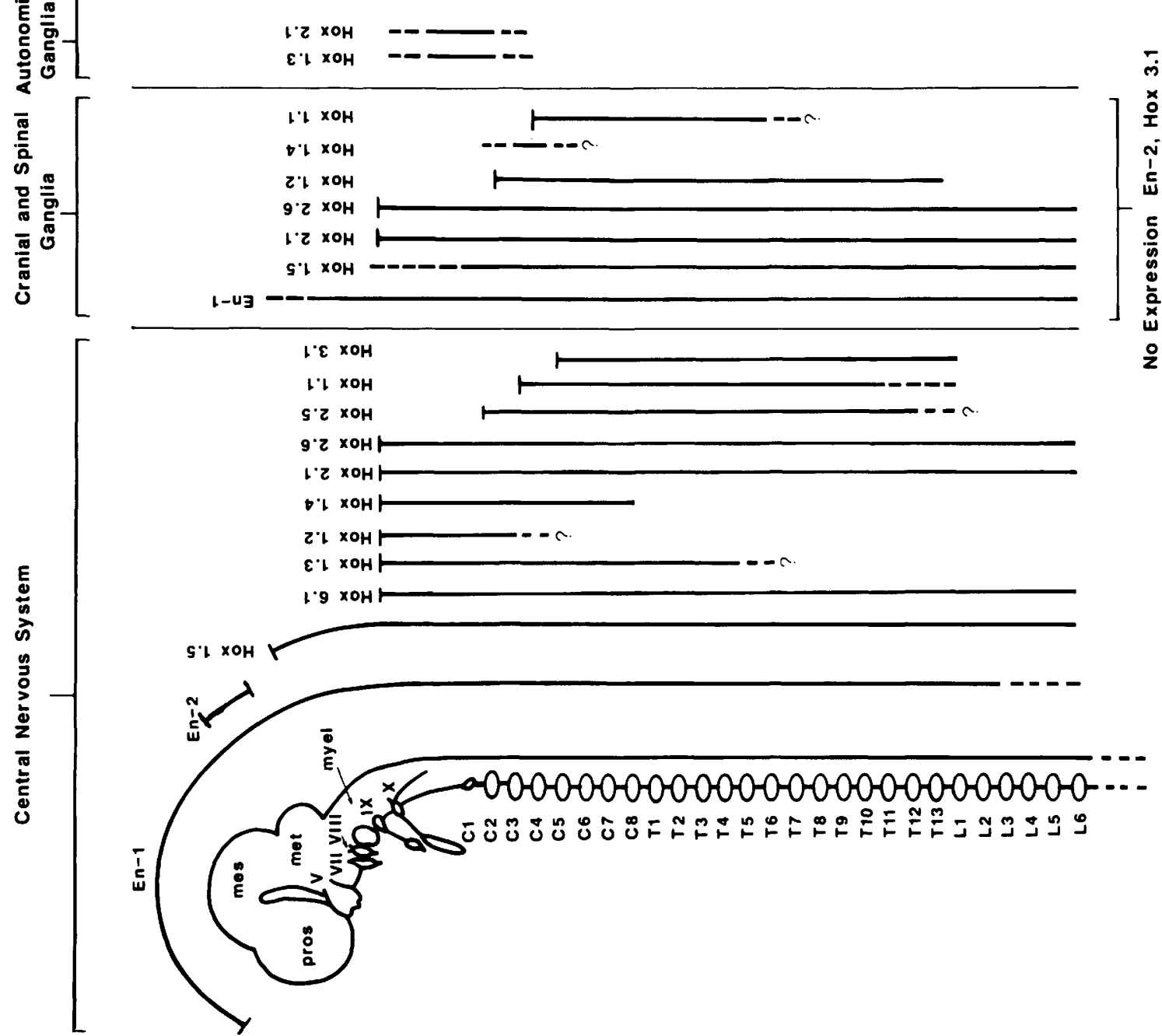
dorsal folds of the neural tube give rise to neural crest derivatives, which form an important component of the nervous system (Le Douarin 1982, 1986; Noden 1984). The major neural crest derivatives in the spinal cord region are the dorsal root ganglia, which are metamerically organized, as shown in Figure 2. In the head region, the neural crest gives rise to much of the mesoderm in the face, including that in the maxillary and mandibular processes, to mesodermal components of organs such as the thyroid and submaxillary glands, and to the nonneuronal (glial) cells of the cranial ganglia. (The neuronal cells of cranial ganglia are derived from neural crests, from ectodermal placodes, or from both.) These ganglia and their associated cranial nerves are important landmarks along the anterior-posterior axis of the head, and their characteristic morphology and innervation patterns make them easily distinguishable, unlike the dorsal root ganglia.

A summary of mouse homeo box gene expression in the 12.5 day embryo is shown in Figure 3. Unfortunately, for many genes the information is incomplete, since reports of in situ hybridization studies have often concentrated on spinal cord and somite derivatives and do not mention the peripheral nervous system (PNS) or visceral organs. However, a number of general conclusions can be reached.

In the CNS different homeo box genes show different anterior-posterior domains of expression that do not correspond to any obvious morphological boundaries. This is particularly striking for En-2, which is localized largely to the metencephalon (Davis et al. 1988), while En-1 expression extends from the forebrain to the end of the spinal cord $(M$. Frohman and G. Martin, pers. comm.). Hox-1.5 has the next most anterior boundary just anterior to the otic vesicle (Fainsod et al. 1987; Gaunt 1987), while Hox-1.2, -1.3, -1.4, -2.1, -2.6, and -6.1 all have anterior limits in the hind brain, posterior to the otic vesicle (Dony and Gruss 1987; Krumlauf et al. 1987; Toth et al. 1987; Graham et al. 1988; Holland and Hogan 1988; Sharpe et al. 1988). Careful comparative studies have yet to be done using probes for these genes on adjacent serial sections and correlating hybridization in the CNS to morphological landmarks such as the cranial ganglia and the transient neuromeric swellings in the brain (Sakai 1987). Such studies should reveal, for example, whether there is overlap between the domains of expression of En-2 and Hox-1.5, or whether they directly interface with each other. Hox-2.5 is expressed more posteriorly, with an anterior limit around the level of the first dorsal root ganglion (Fienberg et al. 1987). By comparison, the anterior limit of Hox-1.1 in the spinal cord is around the level of the third dorsal root ganglion (K. Mahon, pers. comm.). Finally, Hox-3.1 is expressed most posteriorly, beginning at about the level of the fifth dorsal root ganglion (Utset et al. 1987; Holland and Hogan 1988; Le Mouellic et al. 1988; G. Dressler and P. Gruss, pers. comm.). Although the anterior boundary of many of the genes is distinct, the posterior boundary is less so, and its position may alter during development (see later). Although less well studied, the expression of many mouse homeo box genes is also restricted in a dorsoventral or mediolateral manner within the spinal cord (Fienberg et al. 1987; Toth et al. 1987; Utset et al. 1987; Holland and Hogan 1988; Le Mouellic et al. 1988).

Some, but not all, homeo box genes are also expressed in the peripheral nervous system. This has been studied in detail for Hox-2.1, where it appears that cells in the dorsal root ganglia (derived from trunk neural crest), the nodose ganglion (which receives cells from the neural crest and from ectodermal placodes), and the myenteric plexus of the gut (colonized by migration of neural crest from the posterior hind brain) are positive by in situ hybridization (Graham et al. 1988; Holland and Hogan 1988). Other homeo box genes expressed in dorsal root ganglia are Hox-1.1 (G. Dressler, K. Mahon, and P. Gruss, pers. comm.), Hox-1.2 (G. Dressler and P. Gruss, pers. comm.), Hox-1.4 (Toth et al. 1987), Hox-1.5 (Fainsod et al. 1987), Hox-2.6 (Graham et al. 1988), and En-1 (which is also expressed in several cranial ganglia including V, VII, VIII, and X; see Fig. 2) (M. Frohman and G. Martin, pers. comm.). En-2 and Hox-3.1 do not appear to be expressed in dorsal root ganglia (Davis et al. 1988; Le Mouellic et al. 1988). Interestingly, no expression of any homeo box gene has been reported for mesenchymal components of the head (connective tissue, muscle, cartilage, or membrane bone), which derive from neural crest and anterior mesoderm (Noden 1984), nor for mesoderm of the heart, which is also derived from some of the first mesoderm to delaminate from the ectoderm.

Figure 3 also summarizes expression of homeo box genes in mesoderm derived from the somites (prevertebrae), intermediate mesoderm (mesonephros and metanephros), or the lateral plate (lung and stomach). Several general conclusions can be drawn. First, expression in somites does not always mean expression in lateral plate or intermediate mesoderm and vice versa. Second, although anterior-posterior domains of expression in the mesoderm sometimes correlate roughly with domains of expression in the CNS (e.g., Hox-2.1), this is not always the case. For example, the clear discrepancy between the anterior limits of Hox-3.1 expression in the nervous system and in the vertebrae has been noted independently by a number of laboratories (Utset et al. 1987; Holland and Hogan 1988; Le Mouellic et al. 1988; G. Dressler and P. Gruss, pers. comm.). Third, although not thoroughly examined, there is a possible correlation between the order of the Hox-1 genes on the chromosome and the anterior limits of their expression in the somitic mesoderm (see Fig. 3). Finally, as far as we are aware, no spatially localized expression of homeo box genes has been reported yet in the early limb-bud mesenchyme, which is derived from lateral plate. Stage-specific expression of three human homeo box genes, HHO.cl, HHO.c8, and HHO.c13 has been demonstrated by Northern analysis of poly $(A)+$ RNA from limbs of 6- to 8-week-old fetuses. The earliest stage examined corresponds to approximately 13 days p.c. in the mouse when both somite- and lateral plate-derived mesenchyme are present (Mavilio et al. 1986; Simeone et al. 1987).

In conclusion, at 12.5 days p.c. there are clear spatial 
domains of expression of homeo box genes in the CNS, PNS, and mesoderm. Different genes may be expressed in different sets of embryonic structures, and over different regional extents. This is most obvious along the anteroposterior axis, but can also be seen along the mediolateral and dorsoventral axes. Furthermore, for some genes, the domains along these axes may be noncoincident between the CNS, PNS, and mesoderm.

\section{Later stages of development}

In a few cases, comparative in situ hybridization studies have been made between 12.5- and 15.5-day embryos. For Hox-2.1 the conclusion is that the overall level of homeo box gene expression declines, and that, in the CNS at least, the posterior limit of expression becomes more restricted, while the anterior boundary remains the same (Holland and Hogan 1988). It is unclear whether this gradual change in the posterior boundary of Hox-2.1 reflects an underlying anterior-posterior gradient in expression, or whether at earlier stages expression is uniform throughout the spinal cord. Evidence in favor of a gradient has been presented for Hox-1.5 (Gaunt 1987). A similar sharpening of the domain of expression with time has been reported for Hox-1.3 (Dony and Gruss 1987) and Hox-3.1 (Holland and Hogan 1988; Le Mouellic 1988). If this is a general phenomenon for mouse Antennapedia-like genes it may account for some of the discrepancies between different laboratories in assigning the posterior limits of gene expression at a given time, since embryos vary in their rate of development. Finally, it is interesting to note that the regionspecific patterns of Hox-2.1 and -3.1 are still evident in the central nervous system of newborn mice (Awgulewitch et al. 1986; Utset et al. 1987).

\section{Conclusions}

In this review we have considered only mouse homeo box genes related to Drosophila Antennapedia-like and engrailed-like genes. Information on expression is not yet available for genes containing sequences more closely related to the divergent Drosophila homeo boxes, such as in paired, bicoid, or even-skipped.

The general pattern emerging is that the mouse homeo box genes examined so far are expressed in spatial domains along the anteroposterior axis of the embryo. For at least some genes, these spatially restricted regions become evident at the late gastrula or early somite stage (Figs. 2 and 3). By mid to late gestation, each gene is expressed in a characteristic pattern within a few sets of embryonic structures, including the CNS, PNS, somite derivatives, and visceral organs (Fig. 3). These patterns of expression are consistent with, but of course do not prove, a role for homeo box genes in establishing domains of positional value in the mammalian embryo. It is important to note that these patterns may exist in nonsegmented regions of the mesoderm, and that each domains appears initially to be continuous, with no evi- dence of a discontinuous segmental periodicity. As more genes are studied in detail, however, it is possible that metameric patterning may emerge in the overlap of the anterior limits of the different domains.

Although the data are still fragmentary, there may be separate phases of homeo box gene expression and function in mammalian development. During the first, soon after the start of gastrulation, a set of genes (including Hox-1.5 and -3.1) are expressed in both mesoderm and ectoderm. Their role may be to establish broad anteroposterior divisions of the embryo. At present, we can only speculate as to what signals activate these homeo box genes, and control the initial limits of their expression. It is likely that either diffusible factors, or timing mechanisms, acting around gastrulation are involved in early regionalization (Hogan et al. 1985); such mechanisms therefore may be the primary cue for homeo box gene activation. It is possible that elucidation of the time when several homeo box genes are first expressed may help to understand the nature of primary regionalizing cues in the mammalian embryo (Gaunt 1988).

By mid to late gestation, the patterns of expression are more complex, often showing noncoincident anteroposterior domains, and different combinations of genes, in different embryonic structures such as the CNS, PNS, and somitic mesoderm (Fig. 3). In addition, although less easy to analyze because of the extensive cell movements that occur during development, it seems likely that axial limits to expression are also present in the lateral mesoderm. It is possible that these more refined patterns are generated by combinatorial and interactive mechanisms similar to those suggested for the regulation of Drosophila homeotic genes (Gehring 1987). For example, in the CNS, the anterior limit of each homeo box genes domain is generally sharp in early embryos and remains relatively stable /allowing for cell migrations that accompany morphogenesis), while the posterior limit may become more anterior with time. A remarkably similar progressive anterior localization is shown by several Drosophila homeotic genes expressed in the CNS (Akam and Martinez-Arias 1985; Harding et al. 1985). An important area of investigation now is to elucidate the influences that establish and refine these patterns of expression, and to study the effects of experimental perturbations on cell determination during embryogenesis. Obviously, one approach is to misregulate genes in transgenic mice. Another strategy is to combine analysis of specific homeo box gene expression with tissue grafting and in vitro culture. The latter approach is certainly more applicable to vertebrate embryos than to Drosophila, and may give important insight into the roles of germ layer interactions in development. A step toward this goal in Xenopus is the demonstration that influences from the mesoderm permit the expression of a predetermined spatial pattern of expression of a homeo box gene in the neurectoderm (Sharpe et al. 1987).

Not all details of the expression of mouse homeo box genes in development are clearly consistent with a role in regional diversification. In particular, expression at stages later than mid gestation may be partly cell or 
tissue specific, rather than region specific. For example, Hox-2.1 RNA has a nonuniform distribution within the mesoderm of embryonic visceral organs, and a possible role in embryonic induction during organogenesis has been suggested (Holland and Hogan 1988). Hox-1.4 expression is developmentally regulated in different cell types during spermatogenesis, as revealed by in situ hybridization (Rubin et al. 1986) and by Northern analysis of RNA isolated from separated cells (Wolgemuth et al. 1987). Expression of Hox-2.1 RNA has been seen in mature granulocytes in adult mice (Holland and Hogan 1988). Similarly, homeo box gene expression may be cell-type specific in the embryonic and adult CNS (Odenwald et al. 1987; Toth et al. 1987; Davis et al. 1988), and a role in cell determination and differentiation during neurogenesis is a possibility, as suggested for the Drosophila segmentation gene fushi tarazu (Doe et al. 1988). To tackle these problems it is clearly essential to study mouse homeo box gene expression at the single cell level, which must await production of a wider range of specific antibody probes.

Finally, the mechanisms by which homeo box genes exert their putative roles also needs further investigation. Although it is now widely believed that the protein products of homeo box genes act as DNA-binding proteins with roles in regulating gene expression (Gehring 1987), the ultimate target or effector genes have not been identified in any organism. Since the products of these effector genes must ultimately dictate region-specific cellular properties, they may provide the critical link between regionalization and morphological form.

\section{Acknowledgments}

We thank many friends and colleagues for discussion and for providing data prior to publication, in particular Drs. Gregory Dressler, Denis Duboule, Michael Frohman, Steven Gaunt, Anthony Graham, Peter Gruss, Alexandra Joyner, Gail Martin, Katherine Mahon, Chi Nguyen-Huu, Paul Sharpe, Dennis Summerbell, Leslie Toth, and Debra Wolgemuth. We also thank Joe Brock for drawing the diagrams, and Lydia Pearson and Vera Murphy for preparing the manuscript. The authors' work cited here was supported by the Medical Research Council of Great Britain at the National Institute for Medical Research, Mill Hill, London NW71AA.

\section{Note added in proof}

The axial limits of expression of mouse Hox-1.2, -1.3, $-1.4,-1.5,-3.1$, and -6.1 recently have been accurately compared by in situ hybridization at 12.5 days p.c. by S.J. Gaunt, P.T. Sharpe, and D. Duboule, Development (Suppl.) (in press), 1988.

\section{References}

Akam, M.E. and A. Martinez-Arias. 1985. The distribution of Ultrabithorax transcripts in Drosophila embryos. EMBO J. 4: $1689-1700$.

Awgulewitsch, A., M.F. Utset, C.P. Hart, W. McGinnis, and F.H. Ruddle. 1986. Spatial restriction in expression of a mouse homeo box locus within the central nervous system. Nature 320: 328-335.

Beachy, P.A., S.L. Helfand, and D.S. Hogness. 1985. Segmental distribution of bithorax complex proteins during Drosophila development. Nature 313: 545-551.

Bopp, D., M. Burn, S. Baumgartner, G. Frigerio, and M. Noll. 1986. Conservation of a large protein domain in the segmentation gene paired and in functionally related genes of Drosophila. Cell 47: 1033-1040.

Burglin, T.R., C.V.E. Wright, and E.M. DeRobertis. 1987. Translational control in homeo box mRNAs? Nature 330: 701-702.

Carroll, S.B. and M.P. Scott. 1985. Localization of the fushi tarazu protein during Drosophila embryogenesis. Cell 43: $47-57$.

Colberg-Poley, A.M., S.D. Voss, K. Chowdhury, C.L. Stewart, E.F. Wagner, and P. Gruss. 1985. Clustered homeo boxes are differentially expressed during murine development. Cell 43: 39-45.

Colberg-Poley, A.M., S.D. Voss, and P. Gruss. 1988. Homeobox genes of the mouse. In Oxford surveys eukaryotic genes. Oxford University Press, Oxford, (in press).

Coleman, K.G., S.J. Poole, M.P. Weir, W.C. Soeller, and T. Kornberg. 1987. The invected gene of Drosophila: sequence analysis and expression studies reveal a close kinship to the engrailed gene. Genes Dev. 1: 19-28.

Davis, C.A., J. Rossant, and A.L. Joyner. 1988. Expression of the homeo box-containing gene $E n-2$ delineates a specific region of the developing mouse brain. Genes Dev. 2: 361-371.

Desplan, C., J. Theis, and P.H. O'Farrell. 1985. The Drosophila developmental gene, engrailed, encodes a sequence specific DNA binding activity. Nature 318: 630-635.

Di Nardo, S., J.M. Kuner, J. Theis, and P.H. O'Farrell. 1985. Development of embryonic pattern in $D$. melanogaster as revealed by accumulation of the nuclear engrailed protein. Cell 43: 59-69.

Doe, C.Q., Y. Hiromi, W.J. Gehring, and C.S. Goodman. 1988. Expression and function of the segmentation gene fushi tarazu during Drosophila neurogenesis. Science 239: 170175.

Dony, C. and P. Gruss. 1987. Specific expression of the Hox-1.3 homeo box gene in murine embryonic structures originating from or induced by the mesoderm. EMBO I. 6: 2965-2975.

Fainsod, A., L.D. Bogarad, T. Ruusala, M. Lubin, D.M. Crothers, and F.H. Ruddle. 1986. The homeo domain of a murine protein binds $5^{\prime}$ to its own homeo box. Proc. Natl. Acad. Sci. 83: $9532-9536$.

Fainsod, A., A. Awgulewitsch, and F.H. Ruddle. 1987. Expression of the murine homeo box gene Hox-1.5 during embryogenesis. Dev. Biol. 124: 125-133.

Fienberg, A.A., M.F. Utset, L.D. Bogarad, C.P. Hart, A. Awgulewitsch, A. Ferguson-Smith, A. Fainsod, M. Rabin, and F.H. Ruddle. 1987. Homeo box genes in murine development. Curr. Topics Dev. Biol. 23: 233-256.

Gaunt, S.J. 1987. Homeo box gene Hox-1.5 expression in mouse embryos: Earliest detection by in situ hybridization is during gastrulation. Development 101: 51-61.

1988. Mouse homeo box gene transcripts occupy different but overlapping domains in embryonic germ layers and organs: A comparison of Hox-3.1 and Hox-1.5. Development 103: 135-144.

Gaunt, S.J., J.R. Miller, D.J. Powell, and D. Duboule. 1986. Homeobox gene expression in mouse embryos varies with position by the primitive streak stage. Nature 324: 662-664.

Gehring, W.J. 1987. Homeo boxes in the study of development. Science 236: 1245-1252. 
Graham, A., P.W.H. Holland, A. Lumsden, R. Krumlauf, and B.L.M. Hogan. 1988. Expression of the homeobox genes Hox-2.1 and 2.6 during mouse development. In Current topics in microbiology immunology. Springer Verlag, New York. (in press).

Harding, K., C. Wedeen, W. McGinnis, and M. Levine. 1985. Spatially regulated expression of homeotic genes in Drosophila. Science 229: 1236-1242.

Hart, C.P., A. Fainsod, and F.H. Ruddle. 1987. Sequence analysis of the murine Hox-2.2, -2.3, and -2.4 homeo boxes: Evolutionary and structural comparisons. Genomics 1: 182195.

Hill, R.E., A.E. Hall, C.M. Sime, and N.D. Hastie. 1987. A mouse homeobox-containing gene maps near to a developmental mutation. Cytogenet. Cell. Genet. 44: 171-174.

Hogan, B.L.M., P.W.H. Holland, and P.N. Schofield. 1985. How is the mouse segmented? Trends Genet. 1: 67-74.

Hogan, B., F. Costantini, and E. Lacy. 1986. Manipulating the mouse embryo: A laboratory manual. Cold Spring Harbor Laboratory, Cold Spring Harbor, New York.

Holland, P.W.H. and B.L.M. Hogan. 1988. Spatially restricted patterns of expression of the homeobox-containing gene Hox- 2.1 during mouse embryogenesis. Development 102: $159-174$.

Jackson, I.J., P. Schofield, and B.L.M. Hogan. 1985. A mouse homeobox gene is expressed during embryogenesis and in adult kidney. Nature 317: 745-748.

Joyner, A.L. and G.R. Martin. 1987. En-1 and En-2, two mouse genes with sequence homology to the Drosophila engrailed gene: expression during embryogenesis. Genes Dev. 1: $29-38$.

Kessel, M., F. Schulze, M. Fibi, and P. Gruss. 1987. Primary structure and nuclear localization of a murine homeo domain protein. Proc. Natl. Acad. Sci. 84: 5306-5310.

Krumlauf, R., P.W.H. Holland, J.H. McVey, and B.L.M. Hogan. 1987. Developmental and spatial patterns of expression of the mouse homeobox gene Hox-2.1. Development 99: 603617.

Laughon, A., S.B. Carroll, F.A. Storfer, P.D. Riley, and M.P. Scott. 1985. Common properties of proteins encoded by $A n$ tennapedia complex genes of Drosophila melanogaster. Cold Spring Harbor Symp. Quant. Biol. 50: 253-262.

Le Douarin, N. 1964. Étude experimentale de l'organogenese du tube digestif et due foie chez l'embryon de poulet. Bull. Biol. Fr. Belg. 98: 574-676.

1982. The neural crest. Cambridge University Press, England.

- 1986. Cell line segregation during peripheral nervous system ontogeny. Science 231: 1515-1522.

Le Mouellic, H., H. Condamine, and P. Brulet. 1988. Pattern of transcription of the homeo-gene Hox-3.1 in the mouse embryo. Genes Dev. 2: 125-135.

Lonai, P., E. Arman, H. Czosnek, F.H. Ruddle, and C. Blatt. 1987. New murine homeoboxes: Structure, chromosomal assignment, and differential expression in adult erythropoieses. DNA 6: 409-418.

Martin, G.R., E. Boncinelli, D. Dubuole, P. Gruss, I. Jackson, R. Krumlauf, P. Lonai, W. McGinnis, F. Ruddle, and D. Wolgemuth. 1987. Nomenclature for homeo-box-containing genes. Nature 325: 21-22

Martinez-Arias, A. 1986. The Antennapedia gene is required and expressed in parasegments 4 and 5 of the Drosophila embryo. $E M B O$ I. 5: 135-141.

Mavilio, F., A. Simeone, A. Giampaolo, A. Faiella, V. Zappavigna, D. Acampora, G. Poiana, G. Russo, C. Peschle, and E. Boncinelli. 1986. Differential and stage-related expression in embryonic tissues of a new human homeobox gene. Nature 324: 664-668.

Meier, S. and P.P.L. Tam. 1982. Metameric pattern development in the embryonic axis of the mouse. I. Differentiation of the cranial segments. Differentiation 21: 95-108.

Mock, B.A., L.A. D'Hoostelaere, R. Matthai, and K. Hupp. 1987. A mouse homeo box gene, Hox -1.5 , and the morphological locus, $H d$, map to within $1 \mathrm{cM}$ on chromosome 6. Genetics 116: $607-612$.

Munke, M., D.R. Cox, I.J. Jackson, B.L.M. Hogan, and U. Francke. 1986. The murine Hox-2 cluster of homeo box containing genes maps distal on chromosome 11 near the tailshort (TS) locus. Cytogenet. Cell. Genet. 42: 236-240.

Nakatsuji, N., M.H.L. Snow, and C.C. Wylie. 1986. Cinemicrographic study of the cell movement in the primitive-streakstage mouse embryo. J. Embryol. Exp. Morphol. 96: 99-109.

Noden, D.M. 1984. Craniofacial development: New views on old problems. Anat. Rec. 208: 1-13.

Odenwald, W.F., C.F. Taylor, F.J. Palmer-Hill, V. Friedrich, M. Tani, and R.A. Lazzarini. 1987. Expression of a homeo domain protein in non contact-inhibited cultural cells and post mitotic neurons. Genes Dev. 1: 482-496.

Poelmann, R.E. 1981. The formation of the embryonic mesoderm in the early post-implantation mouse embryo. Anat. Embryol. 162: 29-40.

Poole, S.J., L.M. Kauver, B. Drees, and T. Kornberg. 1985. The engrailed locus of Drosophila: Structural analysis of an embryonic transcript. Cell 40: 37-43.

Rubin, M.R., L.E. Toth, M.D. Patel, P. D'Eustachio, and M.C. Nguyen-Huu. 1986. A mouse homeo box gene is expressed in spermatocytes and embryos. Science 233: 663-667.

Rubin, M.R., W. King, L.E. Toth, I.S. Sawczuk, M.S. Levine, P. D'Eustachio, and M.C. Nguyen-Huu. 1987. The murine Hox-1.7 homeobox gene: Cloning, chromosomal location, and expression. Mol. Cell. Biol. 7: 3836-3841.

Rugh, R. 1968. The mouse: Its reproduction and development. Burgess, Minneapolis.

Sakai, Y. 1987. Neurulation in the mouse. I. The ontogenesis of neural segments and the determination of topographical regions in a central nervous system. Anat. Rec. 218: 450-457.

Schulze, F., K. Chowdry, A. Zimmer, U. Drescher, and P. Gruss. 1987. The murine homeo box gene product, Hox-1.1 protein, is growth-controlled and associated with chromatin. Differentiation 36: 130-137.

Sharpe, C.R., A. Fritz, E.M. DeRobertis, and J.B. Gurdon. 1987. A homeobox-containing marker of posterior neural differentiation shows the importance of predetermination in neural induction. Cell 50: 749-758.

Sharpe, P.T., J.R. Miller, E.P. Evans, M.D. Burtenshaw, and S.J. Gaunt. 1988. Isolation and expression of a new mouse homeobox gene. Development 102: 397-407.

Shepherd, J.C.W., W. McGinnis, A.E. Carrasco, A.M. DeRobertis, and W.J. Gehring. 1984. Fly and frog homeo domains show homologies with yeast mating type regulatory proteins. Nature 310: 70-71.

Simeone, A., F. Mavilio, D. Acampora, A. Giampaola, A. Faiella, V. Zappavigna, M. D'Esposito, M. Pannese, G. Russo, E. Boncinelli, and C. Peschle. 1987. Two human homeobox genes, c1 and c8: Structure analysis and expression in embryonic development. Proc. Natl. Acad. Sci. 84: 49144918.

Snell, G.D. and L.C. Stevens. 1966. Early embryology. In Biology of the laboratory mouse, 2nd ed. (ed. E.L. Green), pp. 205-245. McGraw-Hill, New York.

Snow, M.H.L. 1985. The embryonic cell lineage of mammals and the emergence of the basic body plan. In Molecular de- 
terminants of animal form, pp. 73-98. Alan R. Liss, New York.

Tam, P.P.L. and S. Meier. 1982. The establishment of a somitomeric pattern in the mesoderm of the gastrulating mouse embryo. Am. J. Anat. 164: 209-225.

Tam, P.L., S. Meier, and A.E. Jacobson. 1982. Differentiation of the metameric pattern in the embryonic axis of the mouse. II. Somitomeric organization of the presomitic mesoderm. Differentiation 21: 109-122.

Theiler, K. 1972. The house mouse. Springer-Verlag, Berlin, Heidelberg, New York.

Toth, L.E., K.L. Slawin, J.E. Pintar, and M.C. Nguyen-Huu. 1987. Region-specific expression of mouse homeobox genes in the embryonic mesoderm and central nervous system. Proc. Natl. Acad. Sci. 84: 6790-6794.

Utset, M.F., A. Awgulewitsch, F.H. Ruddle, and W. McGinnis. 1987. Region-specific expression of two mouse homeobox genes. Science 235: 1379-1382.

Vakaet, L. 1985. Morphogenetic movements and fate maps in the avian blastoderm. In Molecular determinants of animal form, pp. 99-109. Alan R. Liss, New York.

White, R.A.H. and M. Wilcox. 1984. Protein products of the bithorax complex in Drosophila. Cell 39: 163-171.

Wolgemuth, D.J., C.M. Viviano, E. Gizang-Ginsberg, M.A. Frohman, A.L. Joyner, and G.R. Martin. 1987. Differential expression of the mouse homeobox-containing gene Hox1.4 during male germ cell differentiation and embryonic development. Proc. Natl. Acad. Sci. 84: 5813-5817. 


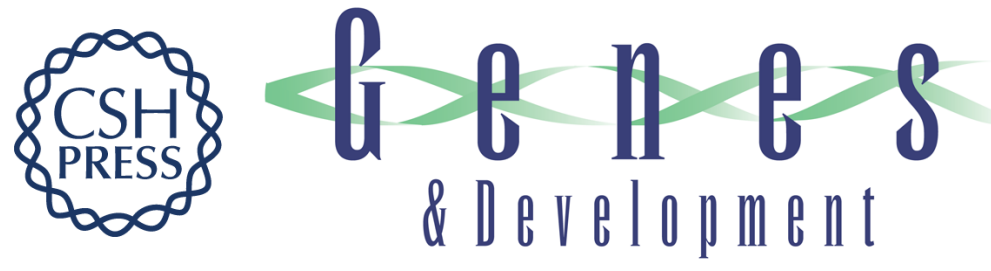

\section{Expression of homeo box genes during mouse development: a review.}

P W Holland and B L Hogan

Genes Dev. 1988, 2:

Access the most recent version at doi:10.1101/gad.2.7.773

References This article cites 59 articles, 22 of which can be accessed free at:

http://genesdev.cshlp.org/content/2/7/773.full.html\#ref-list-1

License

Email Alerting

Service

Receive free email alerts when new articles cite this article - sign up in the box at the top right corner of the article or click here.

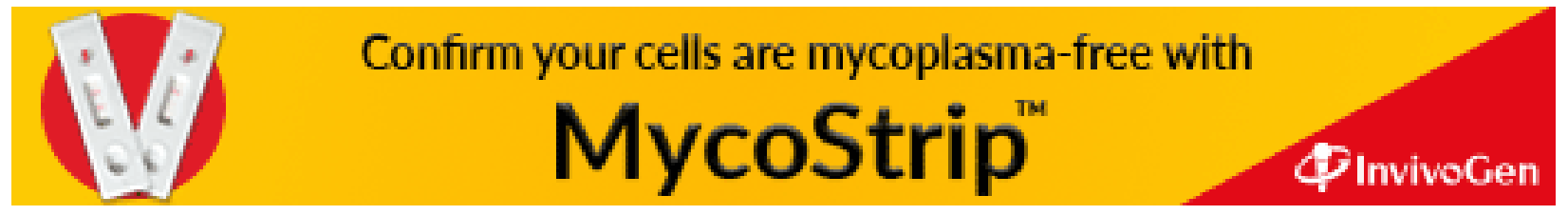

